\title{
Biogas-pH automation control strategy for optimizing organic loading rate of anaerobic membrane bioreactor treating high COD wastewater
}

\author{
Dawei Yu ${ }^{a}$, Jibao Liu ${ }^{a}$, Qianwen Sui ${ }^{a}$, Yuansong Wei ${ }^{\mathrm{a}, \mathrm{b}, *}$

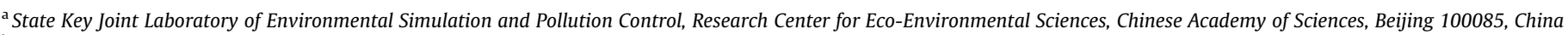 \\ ${ }^{\mathrm{b}}$ Institute of Energy, Jiangxi Academy of Sciences, Nanchang 330096, Jiangxi Province, China
}

\section{H I G H L I G H T S}

- Novel control strategy doubled OLR of AnMBR treating high COD

wastewater.

- COD removal rate achieved $99.1 \%$ allow for efficient and compacted digestion.

- Gas-liquor two phase monitoring sensitively reflected digestion status.

- Dynamic kinetic and $\mathrm{pH}$ titration determined exact threshold for control object.

- The novel strategy seized $\mathrm{CO}_{2}$ for ternary buffer system and maintained $\mathrm{pH}>7.4$.

\section{A R T I C L E I N F O}

\section{Article history:}

Received 25 September 2015

Received in revised form 1 December 2015

Accepted 9 December 2015

Available online 17 December 2015

\section{Keywords:}

Anaerobic membrane bioreactor

High COD wastewater

Online monitoring

Automation control strategy

Alkalinity

\section{G R A P H I C A L A B S T R A C T}

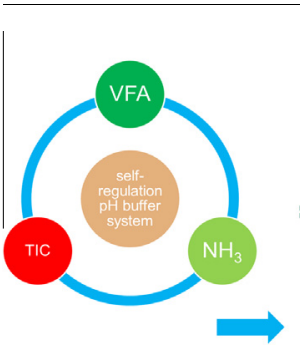

Self-regulation $\mathrm{pH}$ buffer system

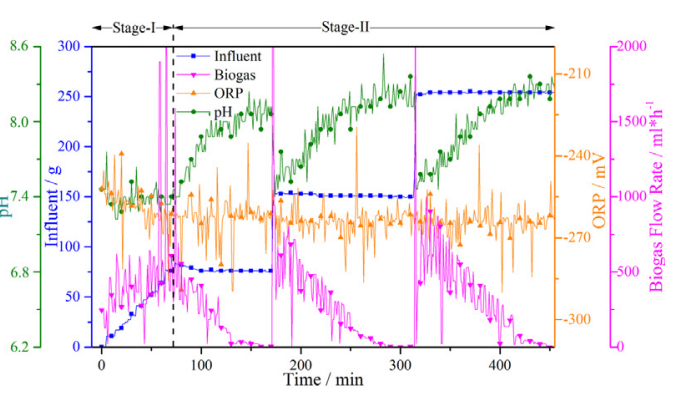

Biogas-pH automation control strategy

\begin{abstract}
A B S T R A C T
Control of organic loading rate (OLR) is essential for anaerobic digestion treating high COD wastewater, which would cause operation failure by overload or less efficiency by underload. A novel biogas-pH automation control strategy using the combined gas-liquor phase monitoring was developed for an anaerobic membrane bioreactor (AnMBR) treating high COD $\left(27.53 \mathrm{~g} \cdot \mathrm{L}^{-1}\right)$ starch wastewater. The biogas-pH strategy was proceeded with threshold between biogas production rate $>98 \mathrm{Nml} \cdot \mathrm{h}^{-1}$ preventing overload and $\mathrm{pH}>7.4$ preventing underload, which were determined by methane production kinetics and $\mathrm{pH}$ titration of methanogenesis slurry, respectively. The OLR and the effluent COD were doubled as $11.81 \mathrm{kgCOD} \cdot \mathrm{kgVSS}^{-1} \cdot \mathrm{d}^{-1}$ and halved as $253.4 \mathrm{mg} \cdot \mathrm{L}^{-1}$, respectively, comparing with a constant OLR control strategy. Meanwhile COD removal rate, biogas yield and methane concentration were synchronously improved to $99.1 \%, 312 \mathrm{Nml} \cdot \mathrm{gCOD}_{\text {in }}^{-1}$ and $74 \%$, respectively. Using the biogas-pH strategy, AnMBR formed a "pH self-regulation ternary buffer system" which seizes carbon dioxide and hence provides sufficient buffering capacity.
\end{abstract}

(c) 2015 Elsevier Ltd. All rights reserved.
* Corresponding author at: State Key Joint Laboratory of Environmental Simulation and Pollution Control, Research Center for Eco-Environmental Sciences, Chinese Academy of Sciences, P.O. Box 2871, Beijing 100085, China. Tel./fax: +86 1062849690 .

E-mail address: yswei@rcees.ac.cn (Y. Wei).

\section{Introduction}

Owing to huge discharged quantity of chemical oxygen demand (COD) (e.g., $4.7 \times 10^{6}$ ton in 2013) and its threat to aquatic environment, the food processing wastewater was targeted in the 10 most polluting industrial wastewaters by the Action Plan for Water Pollution Prevention and Control of China issued recently (Chinese State Council, 2015). Due to high COD removal performance, 
anaerobic membrane bioreactor (AnMBR) could provide a promising way for food processing wastewater treatment to achieve the stringent COD discharging standard (COD $<500 \mathrm{mg} \cdot \mathrm{L}^{-1}$ ) of $\mathrm{GB}$ 8978-1996 without further polishing (Wei et al., 2014). But the organic loading rate (OLR) of the AnMBR at 2.1-8.6 $\mathrm{kgCOD} \cdot \mathrm{m}^{-3} \cdot \mathrm{d}^{-1}$ is relatively low in food processing wastewater treatment by AnMBR, caused by unpredictable constituents of food processing wastewater and limited biomass concentration of AnMBR (Liao et al., 2006; Lin et al., 2012). The unpredictable constituents were related to various food products, seasonal changes of post harvesting and food processing, leading to unstable COD and $\mathrm{pH}$ of wastewater (Lin et al., 2012). With limited biomass, one of the critical challenges of treating high COD wastewater by AnMBR is how to maximize OLR, which would cause high effluent COD concentration and unstable operation by overload (Tay and Zhang, 2000), or less efficient performance by underload (Menardo et al., 2011). Overload of the anaerobic digestion (AD) implies a risk of process upset, and is usually interpreted as the result of methanogenesis inhibition (Pind et al., 2003). Another drawback of overload is inhibition on methanation process, resulting in $30 \%$ losses of potential methane production yield (Fotidis et al., 2014). Methane production losses would not only limit the energy recovery and reduce COD removal rate, but also bring about more expensive downstream treatment, and these will obviously prevent widespread application of the AnMBR in food processing wastewater treatment. There is therefore considerable impetus to optimize OLR of AnMBR treating high COD food processing wastewater.

The online monitoring and automation control strategy provides a new way for real-time optimizing OLR of AnMBR for unpredictable food processing wastewater, and usually consists of online monitoring parameters and automation control strategy. Proper monitoring parameters which could reflect AnMBR state and feed constituents in an accuracy, stability and easy maintenance way, still remain great difficulties due to the complexity of sample pretreatment and huge fluctuations of sample characteristics (Boe et al., 2010). The combined monitoring of both liquid and gasphase parameters is thus considered as an efficient way for the anaerobic digestion (AD) process (Madsen et al., 2011). Lots of methods have been developed for online monitoring of parameters in both the liquid and gas phases of $\mathrm{AD}$, including chromatography (Lenz et al., 2011; Ward et al., 2011), pH titration (Lutzhoft et al., 2014), fuel cell(Liu et al., 2011), and spectroscopy (Ward et al., 2011), but their applications are limited in practice owing to robustness and accuracy. For example, gas chromatography is the most accurate method for volatile fatty acids (VFAs) monitoring in liquid phase, but pretreatment of liquid samples is great challenge due to complexity of AD slurry (Lenz et al., 2011; Ward et al., 2011). Titration could be directly applied in monitoring total VFAs of the AD slurry, but its accuracy is limited by variation of $\mathrm{pH}$ buffer capacity (Lutzhoft et al., 2014). Due to these obstacles of VFA online monitoring, $\mathrm{pH}$ titration of offline samples was more widely applied than online monitoring in biogas plants (Lutzhoft et al., 2014). The most widely used and accurate online monitor parameters of the liquid-phase are $\mathrm{pH}$ and oxidation-reduction potential (ORP) based on electrochemical method which are sensitive and maintenance friendly (Madsen et al., 2011). Furthermore, combination of $\mathrm{pH}$ and ORP also reflects fermentation pathway which links to methanogenesis efficiency (Ren et al., 2002). Spectroscopy has more application in monitoring parameters of gas phase than liquid phase, i.e., near-infrared (NIR) for gas components (Ward et al., 2011), but is limited by sensitivity in biogas monitoring. Recent progress in accuracy of biogas flow rate monitoring made it very attractive approach for gas-phase online monitoring. Monitoring $\mathrm{pH}$ of the liquid-phase and biogas flow rate of the gasphase could work as robust parameters for AnMBR treating high COD food processing wastewater.
The automation control strategy for wastewater treatment by anaerobic digestion is more experiential based on black-box model, such as threshold (Boe et al., 2010), difference index (Dong et al., 2011) and fuzzy logic (Pind et al., 2003), rather than knowledge based on dynamic model remains immaturity (Pind et al., 2003). Based on the combined gas-liquid phase monitoring, many experiential control strategies were thus developed concisely and stably (Dong et al., 2011; Liu et al., 2014; Madsen et al., 2011). The combined gas-liquid phase monitoring makes it possible to indicate digester state by simple parameters, rather than complex parameters in the liquid only. For example, an online monitoring and alert system based on different index of methane production rate and total VFA concentration was developed for a UASB treating sucrose-rich synthetic wastewater (COD $5000 \mathrm{mg} \cdot \mathrm{L}^{-1}$ ) (Dong et al., 2011), resulting in as high as OLR of $10 \mathrm{kgCOD} \cdot \mathrm{m}^{-3} \cdot \mathrm{d}^{-1}$ and as low as effluent COD concentration of $224 \mathrm{mg} \cdot \mathrm{L}^{-1}$. A novel online diagnose system combining microbial fuel cell (MFC), gas flow meter and $\mathrm{pH}$ meter was developed for a upflow anaerobic fixed bed reactor (UAFBR) treating starch wastewater (Liu et al., 2011, 2014), reached OLR of $3.45 \mathrm{kgCOD} \cdot \mathrm{m}^{-3} \cdot \mathrm{d}^{-1}$ and effluent COD $1000 \mathrm{mg} \cdot \mathrm{L}^{-1}$, respectively. Although these complex monitoring strategies were attractive and potential, process analytical technologies (PAT) still need more investigations and progresses in instrument and insight of $\mathrm{AD}$ models (Madsen et al., 2011). In these works, the most commonly used parameters are still $\mathrm{pH}$, VFA and biogas flow rate, which are well related but sensitive in different situations. For potato processing starch wastewater which was of low alkalinity and $\mathrm{pH}$, $\mathrm{pH}$ was a sensitive alert of overload which leads to VFA accumulation and methanogenesis inhibition (Colin et al., 2007; Liu et al., 2014). On the contrary, underload of methanogenesis can be monitored by biogas production rate (Liu et al., 2014; Stromberg et al., 2015). In a summary, the combined monitoring of biogas flow rate in the gas phase and $\mathrm{pH}$ in the liquid phase may provide sensitive thresholds based digestion dynamic. Therefore, the dynamic thresholds could be used for OLR control strategy based on dynamic model in the AnMBR treating high COD food processing wastewater.

Therefore the aims of this study was to develop a new biogas$\mathrm{pH}$ automation control strategy for optimizing organic loading rate (OLR) of AnMBR treating high COD food processing wastewater, in which the combined biogas-pH monitoring and controlling thresholds were determined by methane production kinetics and $\mathrm{pH}$ titration of methanogenesis slurry, respectively. Meanwhile the formation mechanism of $\mathrm{pH}$ self-regulation ternary buffer system was investigated in the AnMBR operated with this control strategy.

\section{Methods}

\subsection{Schemes of AnMBR and its online monitoring $\mathcal{E}$ control system}

A bench-scale AnMBR used in this work consisted of an acidogenesis reactor of $2.0 \mathrm{~L}$ (working volume) and a methanogenesis reactor of $4.0 \mathrm{~L}$ (working volume), respectively. The online monitoring and automation control system consisted of a gas-phase detection unit and a liquid-phase detection unit that connected to a computer through serial ports (RS232/485, Siemens AG, Germany) of programmable logic controller (PLC, SIMATIC S7-200 CPU224XP, Siemens AG, Germany), as illustrated in Fig. 1. The liquid-phase online monitoring unit was a pH sensor (E201-C, Leici Instrument Incorporated, Shanghai, China) for monitoring $\mathrm{pH}$ drop in the methanogenesis reactor due to feed overload. The gas-phase online monitoring unit was a gas flow meter ( $\mu$ Flow, Bioprocess Control AB, Sweden) for monitoring decreases of biogas production rates in the methanogenesis reactor due to feed underload. 


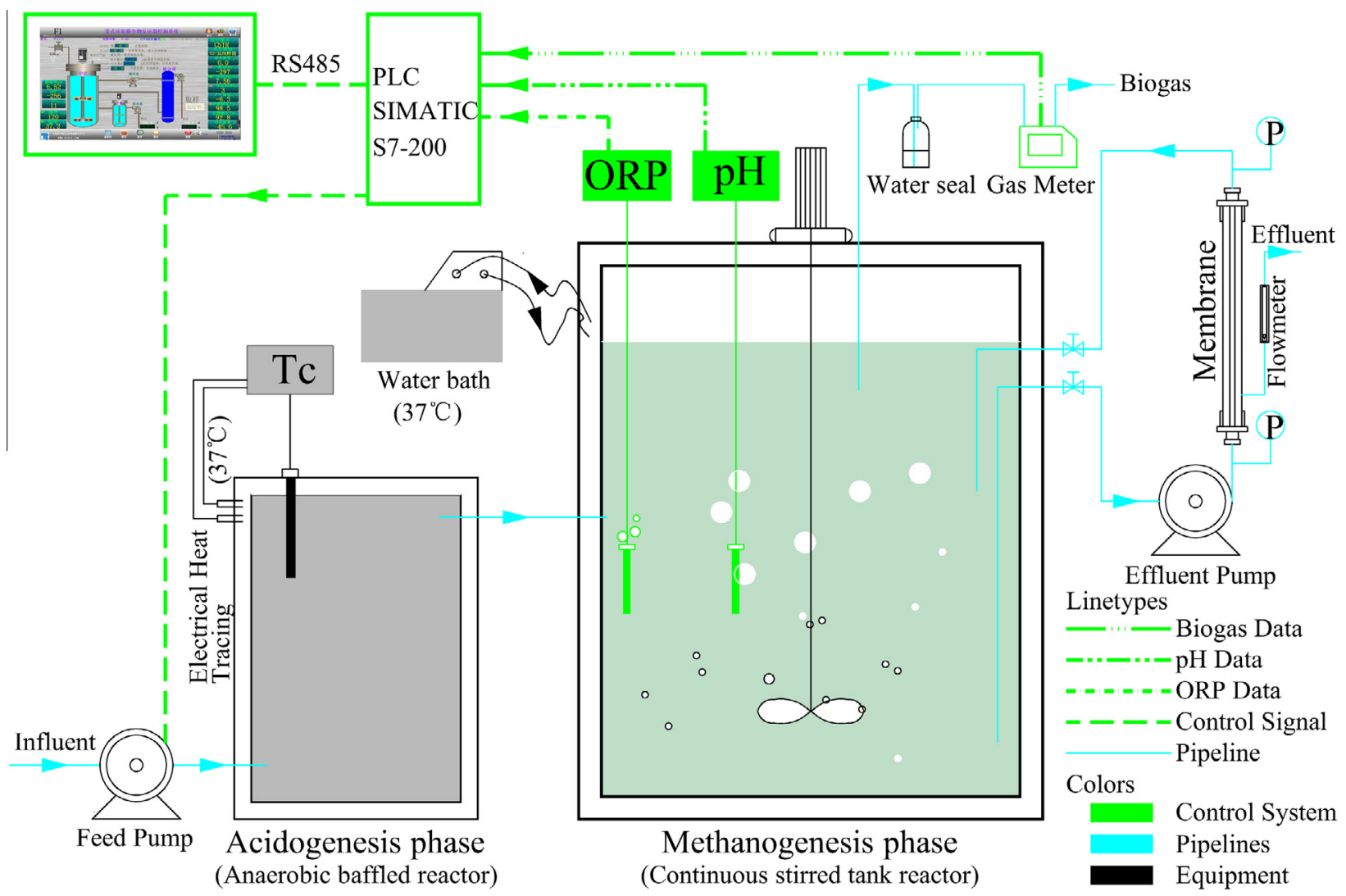

Fig. 1. Schematic diagram of a lab-scale two-phase anaerobic tubular membrane bioreactor.

The software of this automation control system was designed on the basis of an industrial control configuration software (MCGS, Kunluntongtai Co., China), incorporating multi-function of data acquisition, recording and display, especially equipment automation control. The monitoring data were collected by the PLC, and then real-time recorded and proceeded by the software. The feed pump (BT100, Longer Co., China) of starch wastewater was automatically controlled by the software.

\subsection{Dynamic threshold determination for the biogas-pH strategy}

The dynamic threshold of the biogas production rate in the methanogenesis reactor for prevention underload was determined by methane production rates in biochemical methane potential (BMP) test of methanogenesis phase (Ince et al., 1995) according to OLR of the methanogenesis reactor of the AnMBR. The BMP tests for determining methane production rates were carried out in four parallel using a commercial laboratory instrument (AMPTS II, Bioprocess Control, Sweden) which contains 15 parallel cells. Each cell consists of three parts including mesophilic reactor with total volume of $500 \mathrm{ml}, \mathrm{CO}_{2}$ absorption by $\mathrm{NaOH}$ solution $(3 \mathrm{M})$, and gas meter with a data acquisition system (Sambusiti et al., 2014). To simulate methane production rates in the methanogenesis reactor of the AnMBR, an amount of $50 \mathrm{ml}$ effluent of the acidogenesis reactor (as substrates, COD $23.21 \pm 0.46 \mathrm{~g} \cdot \mathrm{L}^{-1}$, VS $6.68 \pm 0.17 \mathrm{~g} \cdot \mathrm{L}^{-1}$ ) was mixed with $150 \mathrm{ml}$ slurry of the methanogenesis reactor (as inoculums, COD $1.66 \pm 0.03 \mathrm{~g} \cdot \mathrm{L}^{-1}$, VS $10.01 \pm 0.21 \mathrm{~g} \cdot \mathrm{L}^{-1}$ ) at OLR of $5.81 \pm 0.11 \mathrm{kgCOD} \cdot \mathrm{m}^{-3} \cdot \mathrm{d}^{-1}$, which total work volume was one twentieth of the methanogenesis reactor. The methane production rates of the BMP test were then converted to the biogas production rate in the methanogenesis reactor through divided by $65 \%$ (aver- age methane concentration in biogas), and then multiplied by 20 ( $\mathrm{V}_{\text {Methanogenesis }} / \mathrm{V}_{\mathrm{BMP}}$ ).

The threshold of $\mathrm{pH}$ in the methanogenesis reactor for prevention overload was selected according to $\mathrm{pH}$ variation in titration of slurry in the methanogenesis reactor, which thresholds were $\mathrm{pH}$ 6.5-8.2 and VFA $1000-1500 \mathrm{mg} \cdot \mathrm{L}^{-1}$ for the optimized biogas and methane production (Mao et al., 2015). To minimize risks of VFA accumulation and OLR underload, the optimized VFA concentration was selected as $1000 \mathrm{mg} \cdot \mathrm{L}^{-1}$. The slurry samples $(100 \mathrm{ml})$ were titrated with $10 \mathrm{~g} \cdot \mathrm{L}^{-1}$ acetic acid solution $1 \mathrm{ml}$ once a time, so that acetic acid concentration in the slurry was increased with step of $100 \mathrm{mg} \cdot \mathrm{L}^{-1}$, and after mixed the stable $\mathrm{pH}$ was measured and recorded (Liu et al., 2014). Other VFAs were also performed exactly the same including propionic, $n$-butyric, iso-butyric, and $n$-valeric acids, respectively.

\subsection{Biogas-pH automation control strategy}

The biogas-pH automation control strategy is shown in Fig. 2. The biogas flow rate in the gas-phase and $\mathrm{pH}$ in the liquid-phase were measured online by the sensors and transported to the PLC, and all detections were conducted once per minute. When the biogas production rate in the methanogenesis reactor was under $98 \mathrm{Nml} \cdot \mathrm{h}^{-1}$, the feedstock was pumped until $\mathrm{pH}$ under 7.4 in the methanogenesis reactor. The threshold data of biogas and $\mathrm{pH}$ were determined by the BMP tests and $\mathrm{pH}$ titration of methanogenesis according to the purposes which were discussed in Section 3.3. Specifically, if a change of sign occurs, the system will not give an immediate judgment. Instead, it would evaluate whether such a signal change is caused by a real change of reactor status or just a temporary fluctuation according to the average of last a quarter and the subsequent points in at least $30 \mathrm{~min}$ (Dong et al., 2011). 


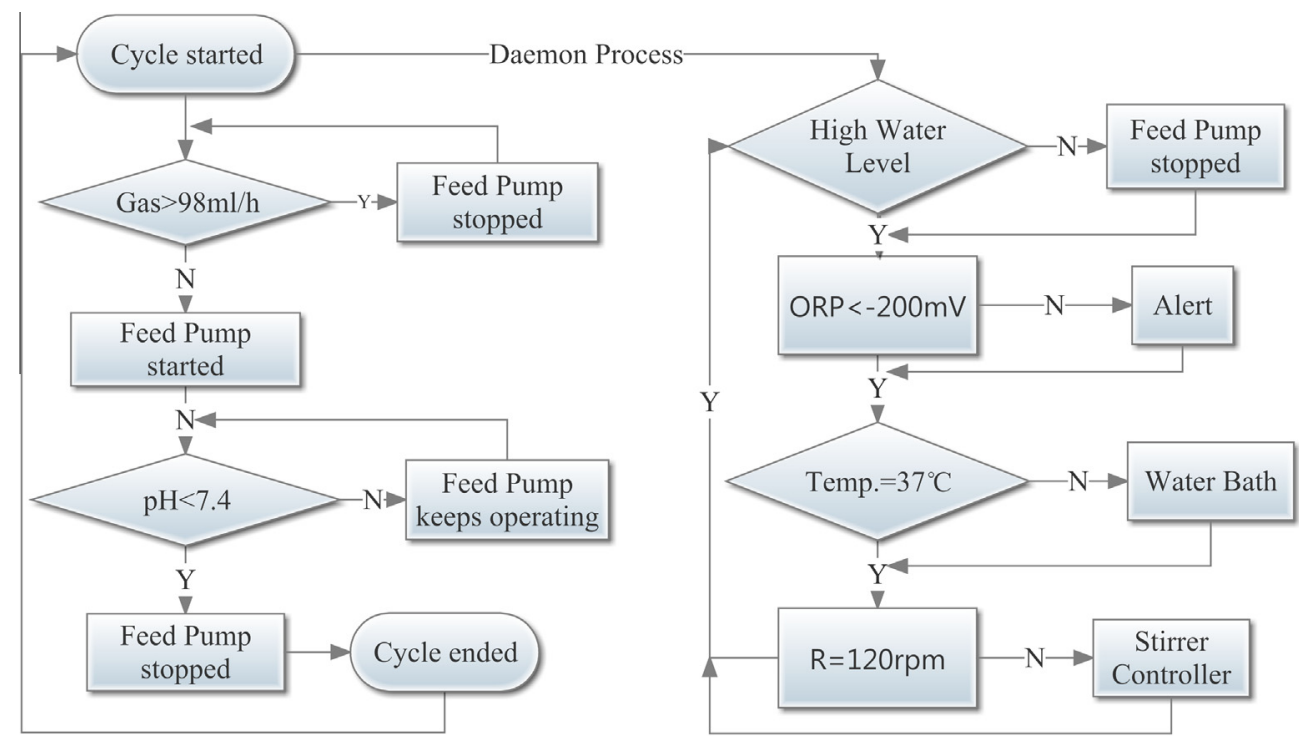

Fig. 2. Flow chart of the biogas-pH automation control strategy for optimizing OLR of the AnMBR.

The automatic control strategy for optimizing OLR of the AnMBR was continuously operated for 18 weeks (day 70-196).

\subsection{Operations of AnMBR}

The seed sludge for the AnMBR was taken from an egg-shaped digester of Xiaohongmen Wastewater Treatment Plant, Beijing, China. The $\mathrm{pH}$ of the seed sludge was $7.31 \pm 0.03$. High COD starch wastewater was used as feedstock, which was characterized at COD of $27.61 \pm 3.49 \mathrm{~g} \cdot \mathrm{L}^{-1}$ and SS of $6.21 \pm 0.84 \mathrm{~g} \cdot \mathrm{L}^{-1}$, respectively, as listed in Table 1. Temperatures in the two reactors of the AnMBR were maintained $37 \pm 0.3{ }^{\circ} \mathrm{C}$ by water bath. The AnMBR was firstly started at a fixed OLR of $5.88 \pm 0.63 \mathrm{kgCOD} \cdot \mathrm{m}^{-3} \cdot \mathrm{d}^{-1}$ according to literature (Fang et al., 2011) before the biogas-pH control strategy was applied. As far as the high rate AD treating high COD food processing wastewater is concerned, the two-phase anaerobic digestion is usually applied for mitigating acidification risk and the methanogenesis is the speed-limited step (Wei et al., 2014). Therefore the OLR in this study refers to the methanogenesis phase of the AnMBR. The raw wastewater was screened $(0.1 \mathrm{~mm})$ before entering the AnMBR to protect membrane.

Operation of the AnMBR was divided as two stages: (1) constant OLR control strategy stage (Stage-I, day 0-70) as the control group; (2) biogas-pH control strategy stage (Stage-II, day 70-200) as the experiment. In the Stage I, the feedstock of the AnMBR was automatically pumped at $30 \mathrm{~s}$ every $10 \mathrm{~min}$ by the PLC. Temperature, mixing, and water level were maintained by the daemon process in the PLC. ORP was used as alert for abnormal status of methanogenesis reactor which was rarely activated in this work. The methanogenesis reactor reached a steady state in terms of OLR at $5.70 \pm 0.49 \mathrm{kgCOD} \cdot \mathrm{m}^{-3} \cdot \mathrm{d}^{-1}$ and effluent COD at $445.17 \pm$ $135.59 \mathrm{mg} \cdot \mathrm{L}^{-1}$ in day $63-84$, but the effluent COD concentration cannot meet the indirect discharge standard (COD $<500 \mathrm{mg} \cdot \mathrm{L}^{-1}$ ) of GB 8978-1996. After the AnMBR was initialized with the constant OLR control strategy, the biogas-pH automation control strategy was loaded in the PLC and conducted to maximize OLR in order to make the effluent COD concentration meet requirements of the abovementioned indirect discharge standard.

\subsection{Analysis}

Samples were taken from the two reactors of the AnMBR twice a week. Chemical oxygen demand (COD) was measured using a
DR2500 (HACH Inc., USA) according to Chinese standard methods (GB11914-1989). Total carbon (TC), total organic carbon (TOC) and total inorganic carbon (TIC) were determined with a liquiTOC II (Elementar Analysensysteme $\mathrm{GmbH}$, Germany) (Wang et al., 2015). Ammonia $\left(\mathrm{NH}_{4}^{+}-\mathrm{N}\right)$, nitrite $\left(\mathrm{NO}_{2}^{-}\right)$, nitrate $\left(\mathrm{NO}_{3}^{-}\right)$, total nitrogen (TN), and $\mathrm{PO}_{4}^{3-}-\mathrm{P}$ were measured using a SmartChem 200 (Alliance Inc., France), and each of their values in Fig. S1 was the average of duplicate samples during the two stages. The soluble COD was measured with the filtrate samples through a $0.22 \mu \mathrm{m}$ membrane. The concentrations of total suspended solids (TS) and volatile suspended solids were determined at $104{ }^{\circ} \mathrm{C}(4 \mathrm{~h})$ and $600{ }^{\circ} \mathrm{C}(2 \mathrm{~h})$, respectively. $\mathrm{CH}_{4}$ and $\mathrm{CO}_{2}$ concentrations in the biogas were determined by a gas chromatography (GC, 4890D, Agilent Inc., USA) equipped with 6 -way valve gas sampler, $2 \mathrm{~m}$ column packed with 13XMS (60/80 mesh) and flame ionization detector (detecting details listed in Supporting Information).

\section{Results and discussion}

\subsection{Performance of the biogas-pH strategy}

The OLR, COD concentration of influent and effluent, and COD removal rate of the AnMBR were shown in Fig. 3 and Table 1. Stage-I was used as the blank group for determining OLR changes and their effects on the AnMBR performance. The initial OLR of the AnMBR in Stage-I was set at $5.28 \mathrm{kgCOD} \cdot \mathrm{m}^{-3} \cdot \mathrm{d}^{-1}$ according to reported OLR of $5.1 \mathrm{kgCOD} \cdot \mathrm{m}^{-3} \cdot \mathrm{d}^{-1}$ of potato starch wastewater (Fang et al., 2011). The effluent COD concentration and COD removal rate were $698 \mathrm{mg} \cdot \mathrm{L}^{-1}$ and $97.3 \%$, respectively. Considering AnMBR has a high OLR for biomass retention, the OLR of the AnMBR during day10-36 was gradually increased to $8.05 \pm 0.90 \mathrm{kgCOD} \cdot \mathrm{m}^{-3} \cdot \mathrm{d}^{-1}$, but the effluent COD concentration increased to $752.80 \pm 263.35 \mathrm{mg} \cdot \mathrm{L}^{-1}$ and the COD removal rate dropped to $97.17 \pm 0.99 \%$, in accordance with other two-phase anaerobic digestion (Rincon et al., 2008). Correspondingly, the $\mathrm{pH}$ in the methanogenesis reactor dropped under 7.4-7.5, which was in accordance with the results while OLR increased to $6.4 \mathrm{kgCOD} \cdot \mathrm{m}^{-3} \cdot \mathrm{d}^{-1}$ (Fang et al., 2011). Due to the fluctuant effluent COD concentration failed to meet the Chinese discharge standard of COD $<500 \mathrm{mg} \cdot \mathrm{L}^{-1}$ (GB 8978-1996), the OLR was then gradually decreased back to the initial OLR of $5.66 \pm 0.50 \mathrm{kgCOD} \cdot \mathrm{m}^{-3} \cdot \mathrm{d}^{-1}$ during day 36-58. This operation resulted in decrease of effluent COD concentration to $402.12 \pm 148.70 \mathrm{mg} \cdot \mathrm{L}^{-1}$ which could meet 


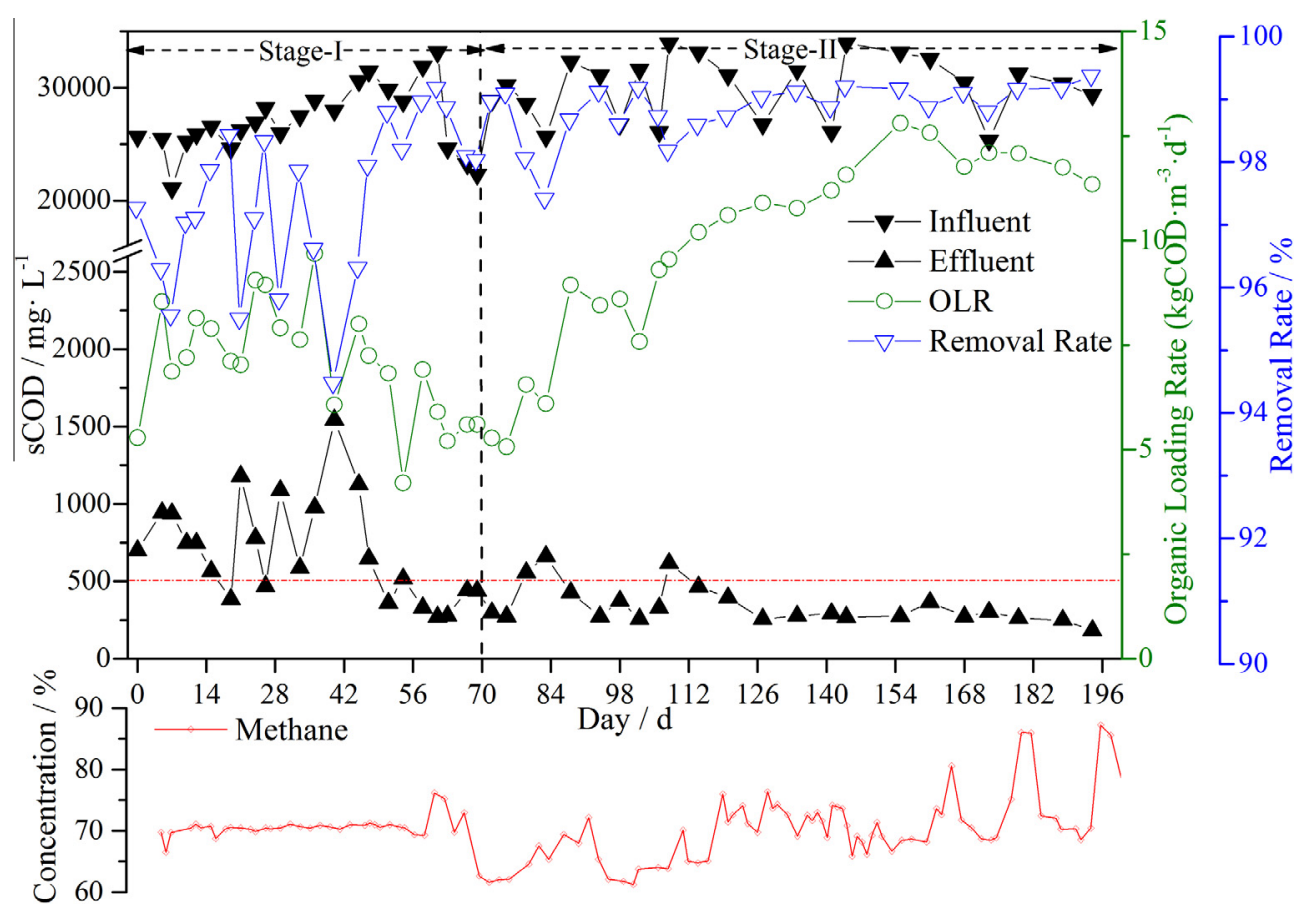

Fig. 3. Effects of the biogas-pH automatic control strategy on OLR and sCOD.

the Chinese discharging standard (GB 8978-1996), and steeply increase of COD removal rate to $98.47 \pm 0.65 \%$ during day $58-70$. From Stage-I results, it was concluded that the OLR of $8.05 \pm 0.90 \mathrm{kgCOD} \cdot \mathrm{m}^{-3} \cdot \mathrm{d}^{-1}$ was too high for the AnMBR operated with the constant OLR operating strategy.

For optimizing the OLR, the biogas-pH automation control strategy was launched in Stage-II. Results demonstrated that a $52.9 \%$ improvement in the OLR, $8.66 \pm 0.25 \mathrm{kgCOD} \cdot \mathrm{m}^{-3} \cdot \mathrm{d}^{-1}$ during day 84-98, occurred after two weeks of this strategy started, compared to that in Stage-I. Meanwhile, effluent COD concentration was decreased to $358 \pm 78.24 \mathrm{mg} \cdot \mathrm{L}^{-1}$, much lower than COD $500 \mathrm{mg} \cdot \mathrm{L}^{-1}$ of the Chinese discharge standard (GB 8978-1996). The effluent COD concentration remained lower than $300 \mathrm{mg} \cdot \mathrm{L}^{-1}$, though the OLR of the AnMBR gradually climb up to $10.45 \pm 1.42 \mathrm{kgCOD} \cdot \mathrm{m}^{-3} \cdot \mathrm{d}^{-1}$ in day $98-161$. These improvements led to the final stead-state (day 161-194) with the OLR of $11.81 \pm 0.31 \mathrm{kgCOD} \cdot \mathrm{m}^{-3} \cdot \mathrm{d}^{-1}$ operating continuously for more than 28 days, $208.7 \%$ higher OLR than that in the steady state of Stage-I (day 36-58). Additionally, effluent COD concentration and COD removal rate were synchronously decreased to $253.4 \pm 43.70 \mathrm{mg} \cdot \mathrm{L}^{-1}$ and improved to $99.1 \pm 0.20 \%$, respectively. These results showed that the biogas-pH automation control strategy not only enhanced stability in high OLR operation of the AnMBR, but also improved performance in COD removal and effluent COD concentration (Table 1 ) of the AnMBR.

The average biogas yield was increased from $275 \pm 61 \mathrm{Nml} \cdot \mathrm{gCOD}_{\text {in }}^{-1}$ (Stage-I) to $312 \pm 49 \mathrm{~mL} \cdot \mathrm{gCOD}_{\text {in }}^{-1}$ with the biogas-pH control strategy (Table 1 ). One important reason for the improvement could be attributed to more influent COD was removed. The average biogas flow rate was doubled as $596 \pm 327 \mathrm{Nml} \cdot \mathrm{h}^{-1}$ compared with the constant strategy, owing to the doubled organic loading rate. And the peak biogas production rate $\left(647.79 \pm 177.96 \mathrm{ml} \cdot \mathrm{h}^{-1}\right)$ in the stable period of Stage-II was also $38 \%$ higher than that $\left(401.30 \pm 115.36 \mathrm{ml} \cdot \mathrm{h}^{-1}\right)$ in the initial period of Stage-II. But the methane concentration did not share the similar increasing trends with biogas flow rate (Fig. 3). It was very stable at the volume concentration of $70.5 \pm 0.6 \%$ in the optimizing period of Stage-I, so did the $\mathrm{pH}$. The methane concentration was decreased with the initiating of the new strategy which might link with insufficient substrate and needs further research (Ahring, 2003). But it recovered to $74.1 \pm 6.3 \%$ during the optimizing and stable periods of Stage-II. And then methane concentration reached several peak points over $80 \%$ which might be attributed to that the higher $\mathrm{pH}$ seizing more carbon dioxide at the end of every control cycle.

The largest obstacle of COD removal is providing sufficient carbonate alkalinity when treating starch wastewater in high rate AD (Ahring, 2003). In order to provide sufficient carbonate alkalinity, many investigations have been carried out, in the effort to reduce the cost necessary to balance the $\mathrm{pH}$ in reactor. For example, one approach was to supply extra alkalinity by bicarbonate to $2000-$ $3000 \mathrm{mg} \cdot \mathrm{L}^{-1}$ and maintained $\mathrm{pH} 7.0-7.5$ only in the start-up period, which $77.5-92.0 \%$ of COD were removed at OLR $10.2-$ $40.0 \mathrm{kgCOD} \cdot \mathrm{m}^{-3} \cdot \mathrm{d}^{-1}$ in an up-flow multi-stage anaerobic reactor (UMAR) (Sun et al., 2012). But the addition of chemicals is the largest operational cost in all high-rate AD system (Romli et al., 1994). Another approach is to make full use of by-production $\mathrm{CO}_{2}$ through recirculation of effluent or biogas, which will be more efficient if coupled with upflow anaerobic sludge blanket (UASB) or Internal Circulation (IC) reactor. The accomplished recirculation ratio, COD removal rate and OLR of an UASB treating starch wastewater were $4, \quad>95 \%$ and $10-16 \mathrm{kgCOD} \cdot \mathrm{m}^{-3} \cdot \mathrm{d}^{-1}$, respectively (Annachhatre and Amatya, 2000). The approach is to make full use of $\mathrm{CO}_{2}$ through the biogas-pH automation control strategy, and to couple with a two-phase anaerobic digestion and membrane separation, details are discussed in the following Section 3.4. The accomplished COD removal rate and OLR in this study were as high as $99.1 \%$ and $11.81 \pm 0.31 \mathrm{kgCOD} \cdot \mathrm{m}^{-3} \cdot \mathrm{d}^{-1}$, respectively. Additionally, a side-effect of higher $\mathrm{pH}$ in the methanogenesis reactor is of course retaining of $\mathrm{CO}_{2}$, resulting in higher methane concentration in the biogas.

\subsection{Procedures of the biogas-pH strategy}

The online monitoring records of biogas production rate, $\mathrm{pH}$, cumulative influent mass, and ORP were shown in Fig. 4a. Biogas production rate and $\mathrm{pH}$ followed different patterns in Stage-I and Stage-II. In the constant OLR control stage (Stage-I, day 0-70), 
Table 1

Feed starch wastewater characteristics, reactor configurations, and operation conditions of AnMBR at different control strategies.

\begin{tabular}{|c|c|c|c|c|c|}
\hline \multicolumn{6}{|l|}{ Feed Starch wastewater (average $\pm S D$ ) } \\
\hline $\operatorname{COD}\left(\mathrm{g} \cdot \mathrm{L}^{-1}\right)$ & $27.53 \pm 4.04$ & \multicolumn{3}{|c|}{ Total Solid $\left(\mathrm{g} \cdot \mathrm{L}^{-1}\right)$} & $9.21 \pm 1.06$ \\
\hline $\mathrm{NH}_{4}^{+}-\mathrm{N}\left(\mathrm{mg} \cdot \mathrm{L}^{-1}\right)$ & $518.57 \pm 232.96$ & \multicolumn{3}{|c|}{ Volatile solids $\left(\mathrm{g} \cdot \mathrm{L}^{-1}\right)$} & $6.17 \pm 8.57$ \\
\hline $\mathrm{NO}_{3}^{+}-\mathrm{N}\left(\mathrm{mg} \cdot \mathrm{L}^{-1}\right)$ & $12.81 \pm 6.83$ & \multicolumn{3}{|c|}{$\mathrm{pH}$} & $4.86 \pm 0.85$ \\
\hline $\mathrm{TN}\left(\mathrm{mg} \cdot \mathrm{L}^{-1}\right)$ & $559.77 \pm 23.7$ & \multicolumn{3}{|l|}{ ORP (mV) } & $27.06 \pm 113.66$ \\
\hline $\mathrm{PO}_{4}^{3-}-\mathrm{P}\left(\mathrm{mg} \cdot \mathrm{L}^{-1}\right)$ & $281.37 \pm 20.41$ & \multicolumn{3}{|c|}{ Electrical conductivity $\left(\mathrm{mS} \cdot \mathrm{cm}^{-1}\right)$} & $7.10 \pm 0.71$ \\
\hline TOC $\left(\mathrm{mg} \cdot \mathrm{L}^{-1}\right)$ & $7531.00 \pm 1678.2$ & \multicolumn{3}{|c|}{$\mathrm{TIC}\left(\mathrm{mg} \cdot \mathrm{L}^{-1}\right)$} & $389.05 \pm 313.78$ \\
\hline \multicolumn{6}{|l|}{ Configurations } \\
\hline Volume of bioreactor (L) & \multicolumn{5}{|l|}{$6 \mathrm{~L}$} \\
\hline Type of acidogenesis reactor & \multicolumn{5}{|c|}{ Anaerobic baffled reactor with $2 \mathrm{~L}$ working volume } \\
\hline Type of methanogenesis reactor & \multicolumn{5}{|c|}{ Continuous stirred-tank reactor with $4 \mathrm{~L}$ working volume } \\
\hline Recycling pump & \multicolumn{5}{|c|}{ Model: FUJ-370A, $Q=35 \mathrm{~L} / \mathrm{min}, P=120 \mathrm{kPa}, 220 \mathrm{~V} 370 \mathrm{~W}$} \\
\hline Membrane module & \multicolumn{5}{|c|}{ Tuber, PVDF, pore size $0.1 \mu \mathrm{m}$, membrane area $0.125 \mathrm{~m}^{2}$} \\
\hline \multicolumn{6}{|l|}{ Operational conditions } \\
\hline \multirow[t]{2}{*}{ Control strategy } & Stage-I/II & \multicolumn{2}{|c|}{ Constant OLR (Stage-I) } & \multicolumn{2}{|c|}{ Biogas-pH (Stage-II) } \\
\hline & Initial & Optimizing & Stable & Optimizing & Stable \\
\hline Time (day) & $1-14 / 70-84$ & $14-58$ & $58-84$ & $84-161$ & $161-194$ \\
\hline Organic loading rate $\left(\mathrm{kg}_{\mathrm{COD}} \cdot \mathrm{kg}_{\mathrm{VSS}}^{-1} \cdot \mathrm{d}^{-1}\right)$ & 5.28 & $8.05 \pm 0.90$ & $5.66 \pm 0.50$ & $8.66 \pm 0.25$ & $11.81 \pm 0.31$ \\
\hline COD Removal Rate (\%) & 97.3 & $97.17 \pm 0.99$ & $98.47 \pm 0.65$ & $98.70 \pm 0.28$ & $99.1 \pm 0.20$ \\
\hline Effluent $\mathrm{COD}\left(\mathrm{mg} \cdot \mathrm{L}^{-1}\right)$ & 698 & $752.8 \pm 263.3$ & $402.1 \pm 148.7$ & $358 \pm 78.24$ & $253.4 \pm 43.70$ \\
\hline pH (Methanogenesis) & $7.82 \pm 0.03$ & $7.55 \pm 0.12$ & $7.27 \pm 0.05$ & $7.60 \pm 0.27$ & $7.83 \pm 0.29$ \\
\hline TIC $\left(\mathrm{mg} \cdot \mathrm{L}^{-1}\right)$ & $364 \pm 29$ & $548 \pm 127$ & $685 \pm 91$ & $672 \pm 161$ & $706 \pm 48$ \\
\hline $\mathrm{NH}_{4}^{+}-\mathrm{N}\left(\mathrm{mg} \cdot \mathrm{L}^{-1}\right)$ & $532 \pm 13$ & $591 \pm 84$ & $827 \pm 149$ & $822 \pm 84$ & $1086 \pm 206$ \\
\hline Biogas flow rate $\left(\mathrm{Nml} \cdot \mathrm{h}^{-1}\right)$ & $255 \pm 92$ & $404 \pm 166$ & $291 \pm 106$ & $429 \pm 239$ & $596 \pm 327$ \\
\hline Biogas yield ( $\left.\mathrm{Nml} \cdot \mathrm{gCOD}_{\mathrm{in}}^{-1}\right)$ & $218 \pm 80$ & $264 \pm 76$ & $275 \pm 61$ & $271 \pm 96$ & $312 \pm 49$ \\
\hline Methane Concentrate (\%) & $69.7 \pm 1.5$ & $70.5 \pm 0.6$ & $67.3 \pm 5.2$ & $69.4 \pm 3.9$ & $74.1 \pm 6.3$ \\
\hline SRT (days) & $\sim 200 \mathrm{~d}$ & & & & \\
\hline
\end{tabular}

starch wastewater was fed with a constant rate, and thus biogas production and $\mathrm{pH}$ randomly fluctuated around an average value which was $483.4 \pm 444.6 \mathrm{ml} \cdot \mathrm{h}^{-1}$ and $7.39 \pm 0.01$, respectively. The $\mathrm{pH}$ data was similar to that of anaerobic digestion fed with potato juice wastewater (Fang et al., 2011). But the biogas production rate was fluctuant in this work rather than inhibited in the literature report (Fang et al., 2011). After the biogas-pH strategy was applied in Stage-II, the wastewater feeding was started by biogas production rate and stopped by $\mathrm{pH}$. After biogas production rate $<98 \mathrm{ml} \cdot \mathrm{h}^{-1}$, the wastewater feeding (with $\mathrm{pH}=4.62 \pm 0.21$ ) was started meanwhile $\mathrm{pH}$ began to decrease. When $\mathrm{pH}$ was dropped $<7.4$, the wastewater feeding was stopped and then biogas production rate recovered immediately.

In stage-II, the pattern of $\mathrm{pH}$ and ORP changes indicated underload and overload of methanogenesis reactor. After the biogas-pH control strategy applied, the biogas production rate gradually decreased from $483.4 \pm 444.6 \mathrm{ml} \cdot \mathrm{h}^{-1}$ to none and the $\mathrm{pH}$ began to increase from 7.39 to over 8.1 , which indicated temporary underload of the methanogenesis phase (Liu et al., 2014). When the biogas production rate was less than $98 \mathrm{ml} \cdot \mathrm{h}^{-1}$ for $30 \mathrm{mins}$, the methanogenesis reactor was fed for preventing underload. The fed was lasted to $\mathrm{pH}$ under 7.40 for precaution of overload (Fang et al., 2011). The ORP of methanogenesis phase was stable around $-263.0 \pm 6.5 \mathrm{mV}$ in both Stage-I and Stage-II (Fig. 4a). The $\mathrm{ORP}$ and the $\mathrm{pH}$ of acidogenic reactor were $-126.3 \pm 19.5 \mathrm{mV}$ and $4.62 \pm 0.21$, respectively, which were tested by a Multi 3210 (WTW GmbH, Germany) twice a week. The dynamic threshold of both biogas and $\mathrm{pH}$ were determined according to kinetic study results of the methanogenesis phase, which was discussed in the next Section 3.3.

During the initial period of Stage-II, the $\mathrm{pH}$ increased from $7.39 \pm 0.01$ to $8.11 \pm 0.01$ and continually increased to $8.12 \pm 0.02$ in the next cycle. This $\mathrm{pH}$ increase relieved the overload of the methanogenesis reactor, and led to an average of 53\% more stable biogas production in the Stage-II $\left(470.97 \pm 208.40 \mathrm{ml} \cdot \mathrm{h}^{-1}\right) \mathrm{com}$ pared to that in the Stage-I $\left(483.37 \pm 444.63 \mathrm{ml} \cdot \mathrm{h}^{-1}\right)$.

Manipulation of $\mathrm{pH}$ variation in the biogas-pH automation control strategy could provide more beneficial conditions to the methanogenesis reactor than the constant OLR strategy, and ultimately led to more stable operation and better performance of the AnMBR, such as higher OLR, higher COD removal rate, lower effluent COD concentration and higher methane production. These beneficial conditions might be less VFA accumulation and periodically relieved ammonia inhibition owe to higher $\mathrm{pH}$ and its periodically increasement. While the OLR was attempted increasing to $6.4 \mathrm{kgCOD} \cdot \mathrm{m}^{-3} \cdot \mathrm{d}^{-1}$ in a typical constant OLR control strategy in this study, the $\mathrm{pH}$ in the methanogenesis reactor was around 7.4-7.5, corresponding to VFAs concentration accumulated to $1000 \mathrm{mg} \cdot \mathrm{L}^{-1}$ (Saddoud and Sayadi, 2007), and hence resulting in average effluent COD $995.17 \pm 350.59 \mathrm{mg} \cdot \mathrm{l}^{-1}$, which failed to fulfill the effluent COD constraint during day 29-47. During a typical biogas-pH strategy controlled cycle, the $\mathrm{pH}$ in the methanogenesis reactor was decreased to 7.4-7.5 when substrate was just fed and gradually increased to 8.1 at the end of the cycle. What makes the biogas-pH automation control strategy attractive is that inhibition caused by VFAs accumulation and underload of OLR were all minimized by the temporal manipulated $\mathrm{pH}$ variations. Meanwhile, ammonia inhibition was temporary relieved by the periodically $\mathrm{pH}$ drop of the biogas-pH strategy. In the beginning of the cycle controlled by the biogas-pH strategy, ammonia inhibition was the critical limiting factor (Fotidis et al., 2014) as sufficient substrates were provided. According to the average ammonia concentration of $780.27 \pm 250.87 \mathrm{mg} \cdot \mathrm{L}^{-1}$ in the methanogenesis reactor, free ammonia nitrogen (FAN) decreased from $132.84 \pm 42.71 \mathrm{mg} \cdot \mathrm{L}^{-1}$ to $29.86 \pm 9.60 \mathrm{mg} \cdot \mathrm{L}^{-1}$ when the $\mathrm{pH}$ in the methanogenesis reactor decreased from 8.1 to 7.4 . The $102.9 \%$ decrease of FAN relieved the ammonia inhibition greatly, and hence accelerated the acclimation for periodically relieving FAN inhibition (Fotidis et al., 2014). And the methanogenesis activities increased in the temporal high OLR period at beginning of the cycle thanks to the acclimation (Nielsen and Angelidaki, 2008). At the end of the cycle with substrates eliminated, when substrate was digested and $\mathrm{pH}$ increased to 8.1, sufficient bicarbonate acid (BA) was more retained for the next cycle. As sufficient BA was retained, the following cycle could benefit from the endogenous BA supplies, and greatly decrease the cost of addition chemicals such as $\mathrm{NaOH}$ 

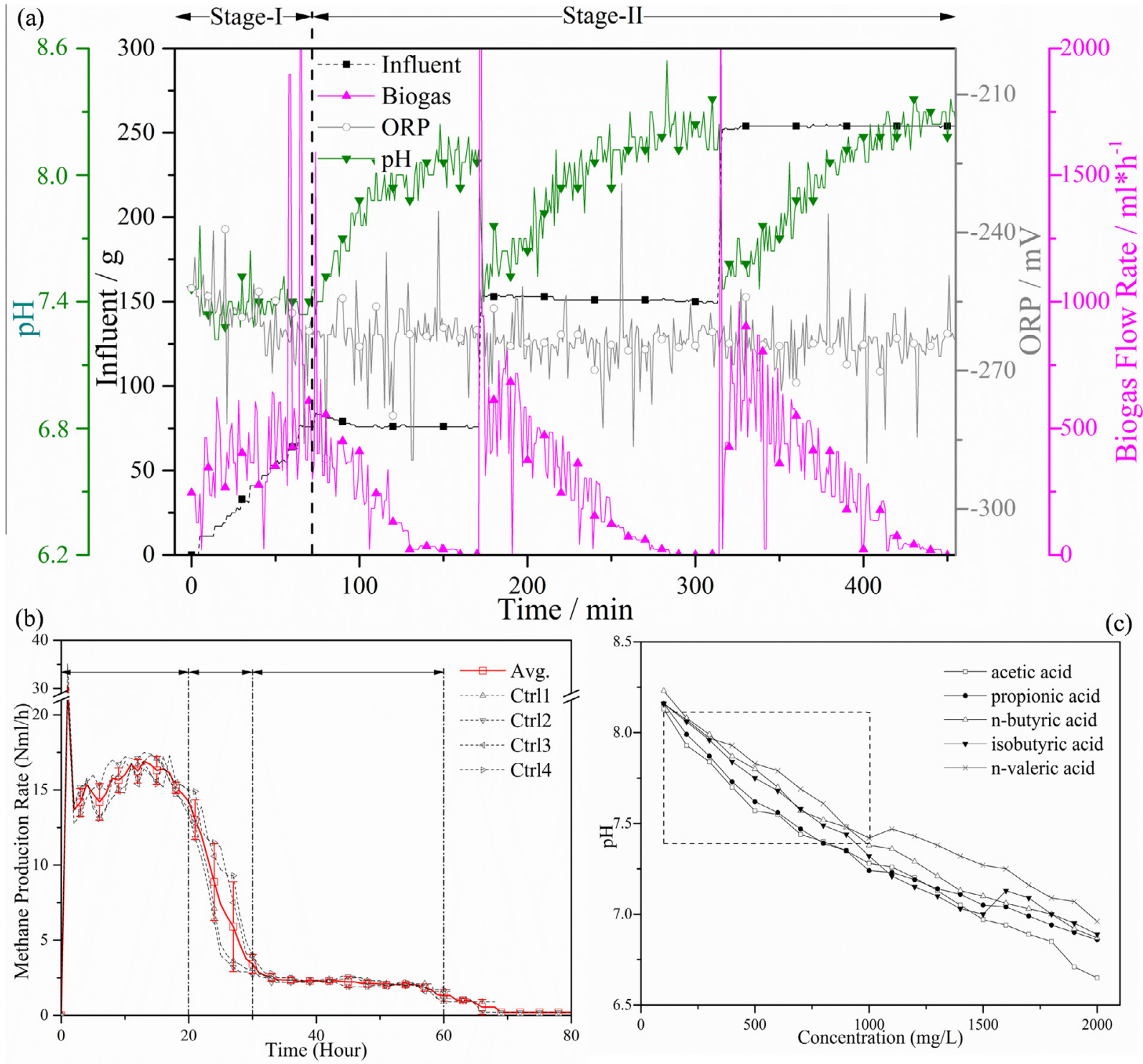

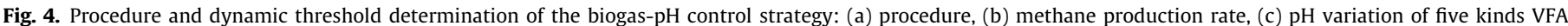
added, respectively.

which is the largest operation cost of the high-rate AD systems treating carbohydrate-base wastewaters (Romli et al., 1994).

\subsection{Dynamic threshold determination of the biogas-pH strategy}

Methane production dynamics in BMP tests of the methanogenesis reactor were reported in Fig. $4 \mathrm{~b}$. The methane production rate can be divided into typical three periods of Michaelis-Menten model (Stromberg et al., 2015), including zero order reaction at the 1 st period and first order reaction in the 2 nd period and lowspeed reaction in the 3 rd period. The methane production rate achieved in the 1 st period was the highest at $16.23 \pm 3.51 \mathrm{Nml} \cdot \mathrm{h}^{-1}$ as sufficient substrates were supplied, corresponding to biogas production rate $479.78 \pm 104.20 \mathrm{Nml} \cdot \mathrm{h}^{-1}$ in the methanogenesis reactor of the AnMBR. The methane production rate decreased rapidly to around $3 \mathrm{Nml} \cdot \mathrm{h}^{-1}$ in the 2 nd period as substrates concentrates decreasing, which the average methane production rate was $3.28 \pm 2.49 \mathrm{Nml} \cdot \mathrm{h}^{-1}$ corresponding to the biogas production rate $98 \pm 74 \mathrm{Nml} \cdot \mathrm{h}^{-1}$ in the methanogenesis reactor of the AnMBR. The methane production rate gradually decreased to around $1 \mathrm{Nml} \cdot \mathrm{h}^{-1}$ in the $3 \mathrm{rd}$ period. To decrease the effluent COD concen- tration, the average biogas production rate of $98 \mathrm{Nml} \cdot \mathrm{h}^{-1}$ in the end of 2 nd period was selected as the underload dynamic threshold, because the substrates concentration is the determining factor in the two periods. Aiming to maximize the OLR, the average biogas production rate $479.78 \mathrm{Nml} \cdot \mathrm{h}^{-1}$ of the 1 st period was selected as the underload dynamic threshold. Meanwhile, these two periods were accomplished in 60hours associate with the HRT $56.5 \mathrm{~h}$ of final Stage-II.

Variation of $\mathrm{pH}$ during titration of slurry in the methanogenesis reactor is shown in Fig. 4c, different VFAs showed similar pH decreasing trends with VFAs dosage increasing. When the dosed acetic acid concentration increased from $100 \mathrm{mg} \cdot \mathrm{L}^{-1}$ to $2000 \mathrm{mg} \cdot \mathrm{L}^{-1}, \mathrm{pH}$ of methanogenesis slurry was decreased from 8.13 to 6.65 , and other VFAs had similar trends to acetic acid. To prevent the methanogenesis reactor of the AnMBR from overload, the overload dynamic threshold was selected as VFA $1000 \mathrm{mg} \cdot \mathrm{L}^{-1}$ corresponding pH ranged from 7.24 to 7.42 (Mao et al., 2015). To minimize the overload risk, the overload threshold was selected at $\mathrm{pH} 7.4$ in this study. What is more, the threshold can be reset according to the kinetic studies for different optimizing objectives. For example, lower biogas dynamic threshold can be selected for 

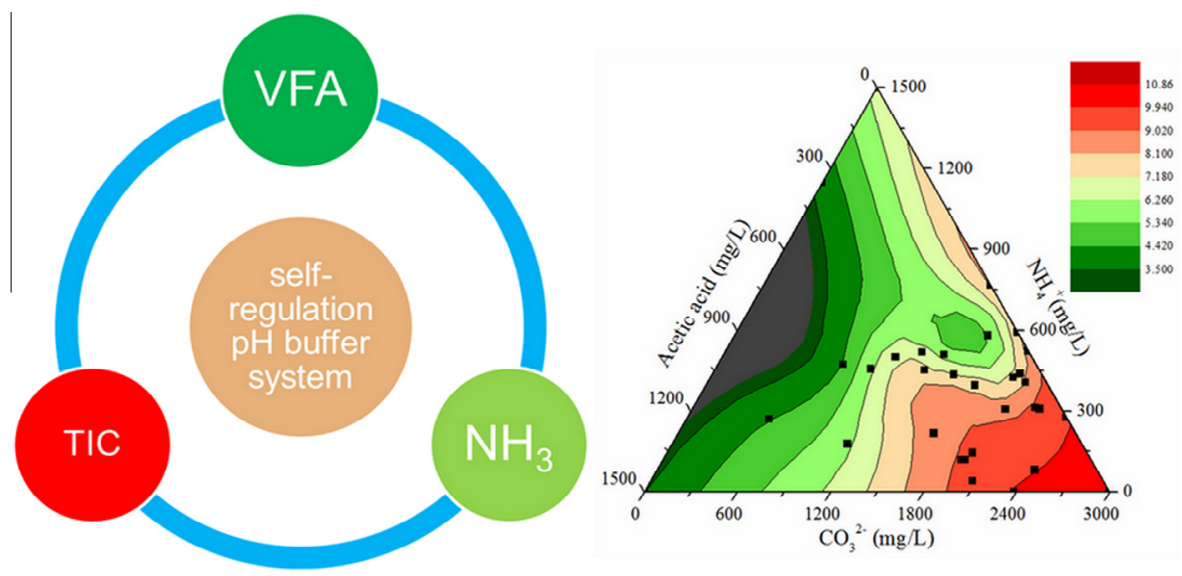

Fig. 5. Mechanism of pH self-buffer capacity of the AnMBR in Stage-II.

higher OLR without the effluent COD constraint, and higher $\mathrm{pH}$ threshold can be selected to minimize the risks of VFAs accumulation.

\subsection{Mechanism of the biogas-pH strategy}

To demonstrate how the $\mathrm{pH}$ variations was dominated by a ternary buffer system composed by VFAs, ammonia and carbonate, a ternary contour was carried out to visualize the $\mathrm{pH}$ variations in the ternary buffer system (Fig. 5). Since truly simulating the $\mathrm{pH}$ variation in the methanogenesis reactor of the AnMBR is exceedingly difficult due to big amounts of electrolytes, the ternary macro-quantity buffer salts were selected for the visualization which represents the critical pH buffer capacity of the methanogenesis (Mao et al., 2015). The $\mathrm{pH}$ of buffer system is dominated by weak acids and mild base salts as Eq. (1). Results of the methanogenesis reactor of the AnMBR showed that concentrations of TIC, TOC and ammonia nitrogen were $915.00 \pm 265.23 \mathrm{mg} \cdot \mathrm{L}^{-1}$, $629.32 \pm 273.21 \mathrm{mg} \cdot \mathrm{L}^{-1}$ and $780.27 \pm 250.87 \mathrm{mg} \cdot \mathrm{L}^{-1}$, respectively (Fig. A.1 and A.2). So the ternary contour ranges of carbonate acid, acetic acid and ammonia were set at $0-3000 \mathrm{mg} \cdot \mathrm{L}^{-1}, 0$ $1500 \mathrm{mg} \cdot \mathrm{L}^{-1}$ and $0-1500 \mathrm{mg} \cdot \mathrm{L}^{-1}$, respectively, which were extended to double value of their practical concentrations in the methanogenesis reactor of the AnMBR. The accordance of ternary contour (Fig. 5b) and pH titration (Fig. 4c) verified the assumption that the variation of $\mathrm{pH}$ largely dominated by the ternary buffer system. Variation ranges of $\mathrm{pH}$ were $3.8-10.86\left(\mathrm{CO}_{3}^{2-}\right), 8.96-3.51$ (acetic acid) and 9.49-6.6 (ammonia), respectively, which were more affected by $\mathrm{CO}_{3}^{2-}$ than by acetic acid and $\mathrm{NH}_{4}^{+}$among the test ranges. In addition, there is a pH basin $(\sim 6.42)$ around $1200 \mathrm{mg}$ $\mathrm{CO}_{3}^{2-} \cdot \mathrm{L}^{-1}$ which is caused by bicarbonate acid $\left(\mathrm{NH}_{4} \mathrm{HCO}_{3}\right)$.

$\mathrm{NH}_{3}+\mathrm{CO}_{2}+\mathrm{H}_{2} \mathrm{O} \rightarrow \mathrm{NH}_{4}^{+}+\mathrm{HCO}_{3}^{-1}$

This is the first time that the pH self-buffer system was discussed in AnMBR, which had such a profound improvement in $\mathrm{pH}$ control without adding extra chemicals. Such pH ternary selfbuffer system produced by the biogas-pH automation control strategy would provide a new approach to solve the acidification problem in AnMBR and the high-rate AD systems compared to the current methods used today.

Provided that online manipulating concentration of ternary buffer system is available, this manipulated variable becomes superior to $\mathrm{pH}$ manipulation in the reactor when the control objective is sufficient alkalinity for AD system. In addition, by spatially separating anaerobic digestion into two reactors, the acidification reactor was enriched with VFAs and the methanogenesis reactor was enriched with ammonium-bicarbonate buffer solution (Rincon et al., 2008). By temporally fed control, the $\mathrm{pH}$ in the methanogenesis reactor can be regulated via VFA dosages or ratio between VFAs and $\mathrm{NH}_{4} \mathrm{HCO}_{3}$ (Zhang et al., 2015). By periodically decreasing the VFAs concentrations, the biogas-pH strategy would enhance the retention of bicarbonate acid which provides more stable $\mathrm{pH}$ and sufficient alkalinity for the $\mathrm{AD}$ system. Thus the $\mathrm{pH}$ in the methanogenesis reactor can be self-regulated by manipulating spatio-temporal distribution of carbonic acid, VFAs and ammonia using the two-phase AD and the fed controlled by the biogas-pH strategy without any extra addition only, which is named as the "self-regulation pH buffer system" in this study.

Another merit of the biogas-pH automation control strategy in this study is acclimatization of ammonia by periodically relieving free ammonia nitrogen (FAN) inhibition. Ammonia is one of the most common inhibitors in anaerobic digestion of food processing wastewater, e.g., starch wastewater or potato juice wastewater. For example, with a low ammonia concentration around 800$1000 \mathrm{mg} \cdot \mathrm{L}^{-1}$, increased VFAs results in $\mathrm{pH}$ decrease, and then FAN decreases, ammonia inhibition is thus mitigated partly (Fotidis et al., 2014; Nielsen and Angelidaki, 2008). Ammonia, VFAs and FAN form a mutual inhibition system for methanogens acclimatization as "inhibited steady state" (Angelidaki and Ahring, 1993). The state could be regulated by spatial and temporal coordination among VFAs, ammonia and carbonic acid in the methanogenesis reactor. If provided relative higher $\mathrm{pH}$, carbonic acid would retain more in the methanogenesis reactor which results in a higher carbonate alkalinity (Braun et al., 1981). The carbonate combined with ammonia and VFAs could thus form a selfregulation $\mathrm{pH}$ buffer which could provide a more stable $\mathrm{pH}$ environment for the $\mathrm{AD}$ system. By periodically decreasing FAN concentration, ammonia acclimatization could be enhanced and ultimately result in a higher COD removal rate over $99 \%$ in this study. As ammonia inhibition was acclimated, ammonia would become a critical part of the ternary self-regulation $\mathrm{pH}$ buffer system rather than major inhibitor in the high rate $\mathrm{AD}$ system.

\section{Conclusions}

This study demonstrates that the biogas-pH strategy, basing on gas-liquor two phase monitoring and dynamic kinetics thresholds controlling, allows for an AnMBR operating with doubled OLR $\left(11.81 \mathrm{kgCOD} \cdot \mathrm{kgVSS}^{-1} \cdot \mathrm{d}^{-1}\right)$ and halved effluent COD (253.4 mg. $\mathrm{L}^{-1}$ ) when it treats high COD wastewater without adding alkalinity. The methane production kinetics and $\mathrm{pH}$ titrations were used as effective methods for determined the thresholds of biogas-pH strategy, which were biogas production rate $>98 \mathrm{Nml} \cdot \mathrm{h}^{-1}$ preventing overload and $\mathrm{pH}>7.4$ preventing under- 
load. Using biogas-pH strategy, AnMBR formed a "pH selfregulation ternary buffer system" containing VFAs, ammonia and bicarbonate which promoted $\mathrm{pH}$ over 7.4 and hence enhanced carbon dioxide seizing.

\section{Author contributions}

The manuscript was written through contributions of all authors. All authors have given approval to the final version of the manuscript.

\section{Notes}

The authors declare no conflict of interest.

\section{Acknowledgements}

This work was funded by the Major Science and Technology Program for Water Pollution Control and Treatment of China (2012ZX07203-002; 2015ZX07203-005), and the Project for Jiangxi-CAS Collaborative Innovation Team-building (2014SYXTCX-02).

\section{Appendix A. Supplementary data}

Supplementary data associated with this article can be found, in the online version, at http://dx.doi.org/10.1016/j.biortech.2015.12. 010.

\section{References}

Ahring, B.K., 2003. Biomethanation I. Springer, Netherlands. http://dx.doi.org/ $10.1007 / 3-540-45839-5,50-52$.

Angelidaki, I., Ahring, B.K., 1993. Thermophilic anaerobic-digestion of livestock waste - the effect of ammonia. Appl. Microbiol. Biotechnol. 38 (4), 560-564.

Annachhatre, A.P., Amatya, P.L., 2000. UASB treatment of tapioca starch wastewater. J. Environ. Eng. ASCE 126 (12), 1149-1152.

Boe, K., Batstone, D.J., Steyer, J.P., Angelidaki, I., 2010. State indicators for monitoring the anaerobic digestion process. Water Res. 44 (20), 5973-5980.

Braun, R., Huber, P., Meyrath, J., 1981. Ammonia toxicity in liquid piggery manure digestion. Biotechnol. Lett. 3 (4), 159-164.

Chinese State Council. 2015. The Action Plan for Water Pollution Prevention and Control.

Colin, X., Farinet, J.L., Rojas, O., Alazard, D., 2007. Anaerobic treatment of cassava starch extraction wastewater using a horizontal flow filter with bamboo as support. Bioresour. Technol. 98 (8), 1602-1607.

Dong, F., Zhao, Q.B., Li, W.W., Sheng, G.P., Zhao, J.B., Tang, Y., Yu, H.Q., Kubota, K., Li, Y.-Y., Harada, H., 2011. Novel Online monitoring and alert system for anaerobic digestion reactors. Environ. Sci. Technol. 45 (20), 9093-9100.

Fang, C., Boe, K., Angelidaki, I., 2011. Biogas production from potato-juice, a byproduct from potato-starch processing, in upflow anaerobic sludge blanket (UASB) and expanded granular sludge bed (EGSB) reactors. Bioresour. Technol. 102 (10), 5734-5741.

Fotidis, I.A., Wang, H., Fiedel, N.R., Luo, G., Karakashev, D.B., Angelidaki, I., 2014. Bioaugmentation as a solution to increase methane production from an ammonia-rich substrate. Environ. Sci. Technol. 48 (13), 7669-7676.

Ince, O., Anderson, G.K., Kasapgil, B., 1995. Control of organic loading rate using the specific methanogenic activity test during start-up of an anaerobic-digestion system. Water Res. 29 (1), 349-355.
Lenz, M., van Hullebusch, E.D., Farges, F., Nikitenko, S., Corvini, P.F., Lens, P.N., 2011 Combined speciation analysis by X-ray absorption near-edge structure spectroscopy, ion chromatography, and solid-phase microextraction gas chromatography-mass spectrometry to evaluate biotreatment of concentrated selenium wastewaters. Environ. Sci. Technol. 45 (3), 1067-1073.

Liao, B.Q., Kraemer, J.T., Bagley, D.M., 2006. Anaerobic membrane bioreactors: applications and research directions. Crit. Rev. Environ. Sci. Technol. 36 (6), 489-530.

Lin, H.J., Gao, W.J., Meng, F.G., Liao, B.Q., Leung, K.T., Zhao, L.H., Chen, J.R., Hong, H.C. 2012. Membrane bioreactors for industrial wastewater treatment: a critical review. Crit. Rev. Environ. Sci. Technol. 42 (7), 677-740.

Liu, Z., Liu, J., Zhang, S., Xing, X.H., Su, Z., 2011. Microbial fuel cell based biosensor for in situ monitoring of anaerobic digestion process. Bioresour. Technol. 102 (22), 10221-10229.

Liu, Z.D., Liu, J., Li, B.M., Zhang, Y.H., Xing, X.H., 2014. Focusing on the process diagnosis of anaerobic fermentation by a novel sensor system combining microbial fuel cell, gas flow meter and $\mathrm{pH}$ meter. Int. J. Hydrogen Energy 39 (25), 13658-13664.

Lutzhoft, H.C., Boe, K., Fang, C., Angelidaki, I., 2014. Comparison of VFA titration procedures used for monitoring the biogas process. Water Res. 54, 262-272.

Madsen, M., Holm-Nielsen, J.B., Esbensen, K.H., 2011. Monitoring of anaerobic digestion processes: a review perspective. Renew. Sustain. Energy Rev. 15 (6), 3141-3155.

Mao, C.L., Feng, Y.Z., Wang, X.J., Ren, G.X., 2015. Review on research achievements of biogas from anaerobic digestion. Renew. Sustain. Energy Rev. 45, 540-555.

Menardo, S., Gioelli, F., Balsari, P., 2011. The methane yield of digestate: effect of organic loading rate, hydraulic retention time, and plant feeding. Bioresour. Technol. 102 (3), 2348-2351.

Nielsen, H.B., Angelidaki, I., 2008. Strategies for optimizing recovery of the biogas process following ammonia inhibition. Bioresour. Technol. 99 (17), 7995-8001.

Pind, P.F., Angelidaki, I., Ahring, B.K., Stamatelatou, K., Lyberatos, G., 2003. Monitoring and control of anaerobic reactors. Adv. Biochem. Eng. Biotechnol $82,135-182$.

Ren, N.Q., Zhao, D., Chen, X.L., Li, J.Z., 2002. Mechanism and controlling strategy of the production and accumulation of propionic acid for anaerobic wastewater treatment. Sci. China Ser. B Chem. 45 (3), 319-327.

Rincon, B., Borja, R., Gonzalez, J.M., Portillo, M.C., Saiz-Jimenez, C., 2008. Influence of organic loading rate and hydraulic retention time on the performance, stability and microbial communities of one-stage anaerobic digestion of two-phase olive mill solid residue. Biochem. Eng. J. 40 (2), 253-261.

Romli, M., Greenfield, P.F., Lee, P.L., 1994. Effect of recycle on a two-phase high-rate anaerobic wastewater treatment system. Water Res. 28 (2), 475-482.

Saddoud, A., Sayadi, S., 2007. Application of acidogenic fixed-bed reactor prior to anaerobic membrane bioreactor for sustainable slaughterhouse wastewater treatment. J. Hazard. Mater. 149 (3), 700-706.

Sambusiti, C., Rollini, M., Ficara, E., Musatti, A., Manzoni, M., Malpei, F., 2014 Enzymatic and metabolic activities of four anaerobic sludges and their impact on methane production from ensiled sorghum forage. Bioresour. Technol. 155, $122-128$.

Stromberg, S., Nistor, M., Liu, J., 2015. Early prediction of Biochemical Methane Potential through statistical and kinetic modelling of initial gas production. Bioresour. Technol. 176, 233-241.

Sun, L., Wan, S., Yu, Z., Wang, Y., Wang, S., 2012. Anaerobic biological treatment of high strength cassava starch wastewater in a new type up-flow multistage anaerobic reactor. Bioresour. Technol. 104 (1), 280-288.

Tay, J.H., Zhang, X., 2000. Stability of high-rate anaerobic systems. I: performance under shocks. J. Environ. Eng. 126 (8), 713-725.

Wang, J.X., Li, K., Wei, Y.S., Cheng, Y.T., Wei, D., Li, M., 2015. Performance and fate of organics in a pilot MBR-NF for treating antibiotic production wastewater with recycling NF concentrate. Chemosphere 121, 92-100.

Ward, A.J., Bruni, E., Lykkegaard, M.K., Feilberg, A., Adamsen, A.P., Jensen, A.P., Poulsen, A.K., 2011. Real time monitoring of a biogas digester with gas chromatography, near-infrared spectroscopy, and membrane-inlet mass spectrometry. Bioresour. Technol. 102 (5), 4098-4103.

Wei, Y.S., Yu, D.W. Chao, L., 2014. Anaerobic membrane bioreactors for treating agricultural and food processing wastewater at high strength. Environ. Sci. 35 (4), 1613-1622.

Zhang, W., Wu, S., Guo, J., Zhou, J., Dong, R., 2015. Performance and kinetic evaluation of semi-continuously fed anaerobic digesters treating food waste: role of trace elements. Bioresour. Technol. 178, 297-305. 